Terbit online pada laman web jurnal : http://teknosi.fti.unand.ac.id/

Jurnal Nasional Teknologi dan Sistem Informasi

ISSN (Print) 2460-3465 | ISSN (Online) 2476-8812 |

Studi Kasus

\title{
Pencarian Kelompok Tani Menggunakan Sistem Informasi Geografis Bagi Penyuluh Di Kabupaten Agam
}

\author{
Yossi Prima Ariyani ${ }^{a}$, Haris Suryamen $^{a}$, Fajril Akbar $^{a}$ \\ ${ }^{a}$ Jurusan Sistem Informasi, Universitas Andalas, Kampus Limau Manis, Padang 25163, Indonesia
}

\begin{tabular}{|c|}
\hline INFORMASI ARTIKEL \\
\hline $\begin{array}{l}\text { Sejarah Artikel: } \\
\text { Diterima Redaksi: } 10 \text { Oktober } 2017 \\
\text { Revisi Akhir: } 29 \text { November } 2017 \\
\text { Diterbitkan Online: } 31 \text { Desember } 2017\end{array}$ \\
\hline KATA KUNCI \\
\hline$S I G$ \\
\hline Penyuluh Tani, \\
\hline Kabupaten Agam \\
\hline KORESPONDENSI \\
\hline Telepon:+62 751-9824667 \\
\hline E-mail: ijab@fti.unand.ac.id \\
\hline
\end{tabular}

\section{A B S $\mathbf{S}$ T R A C $\mathbf{T}$}

Agam regency is one district in West Sumatera which is $38,20 \%$ of its population work in agriculture sector. The government of Agam greatly promotes the development of the agricultural sector with the development of institutions and commodities of every farmer group. Counseling for each farmer group conducted by counselors and managed by the Agency for Agricultural Extension of Fishery and Food Security (BP4K2P). With the number of farmer groups of approximately 1737 groups and spread over $2,232.30 \mathrm{~km} 2$ will make it difficult for BP4K2P especially extension workers to know the location of each farmer group. A farmer group-based information system becomes a solution in finding information for each farmer group. Waterfall model is used as software development life-cycle in this research. Its built from sequential process sequences that cover the stages of analysis, design, coding, and testing. Analysis obtained the functional requirements of the system is formulated with the ability to search by name of farmer groups, districts, type of groups and commodities and display the route to the location of farmer groups. The application is built on the web using Google Maps as the base map. Spatial data processing utilizes PostGIS features. System testing is done with blackbox testing that focuses on the functionality of the system. The results of tests conducted by seven testers on the 7 functional requirements indicate that the system built has been in accordance with the functional requirements of the system designed.

\section{PENDAHULUAN}

Kabupaten Agam merupakan salah satu dari 19 kabupaten/kota yang ada di Provinsi Sumatera Barat dengan luas daerah \pm 2.232,30 kilometer persegi dengan total penduduk pada tahun 2014 sebanyak 466.978 jiwa. Menurut data Badan Pusat Statistik Kabupaten Agam tahun 2015, 38,20 \% dari jumlah penduduknya menjadikan pertanian sebagai mata pencaharian utamanya. Pemerintah sangat mendorong berkembangnya sektor pertanian di Kabupaten Agam dengan melakukan pengembangan sumber daya manusia dan komoditas pertanian melalui kelompok tani. Kelompok tani memiliki manfaat sebagai forum belajar berusaha tani dan berorganisasi, wahana kerja sama, dan unit produksi usaha tani [1]. Program-program bantuan pemerintah seperti penyaluran pupuk bersubsidi, penyuluhan teknologi pertanian, bantuan bibit unggul, kredit usaha tani bersubsidi, dan programprogram lainnya disalurkan melalui kelompok tani.

Di Kabupaten Agam, penyuluhan pertanian oleh penyuluh yang dikelola oleh BP4K2P. Dengan jumlah kelompok tani sebanyak 1.737 kelompok yang tersebar di seluruh Kabupaten Agam, setiap penyuluah kesulitan mengetahui informasi setiap kelompok tani yang ada terutama tempat kedudukannya.
Pemanfaatan suatu Sistem Informasi Geografi (SIG) menjadi solusi bagi permasalahan yang terjadi karena penyajian data yang bereferensikan geografis [2]. SIG juga telah dimanfaatkan untuk pembuatan model bagi pengendalian kepemilikan ternak sapi di Nusa Tenggara Barat [3]. Di Sukabumi, juga telah dikembangkan pemantauan penyebaran hewan ternak dengan memanfaatkan SIG [4]. Pemanfaatan fitur SIG untuk pencarian berbagai objek berdasarkan posisi geografisnya juga telah banyak dilakukan sebelumnya [5][6][7][8][9]. Oleh karena itu dalam penelitian ini dirumuskan bagaimana merancang dan membangun sebuah SIG penyebaran kelompok tani Kabupaten Agam.

Sistem yang dibangun memanfaatkan media web karena kemudahannya diakses melalui seluruh lingkungan intranet maupun internet untuk mengintegrasikan, menyebarkan, dan mengkomunikasikan informasi geografis secara visual di word wide web. Google Maps juga menyediakan layanan Google Maps Application Programming Interface (API) yang memungkinkan para pengembang untuk mengintegrasikan Google Maps ke dalam website masing-masing dengan menambahkan data point sendiri [5][10]. Google Maps API dapat diakses lewat javascript agar Google Map bisa ditampilkan kedalam web atau aplikasi. 


\section{METODOLOGI}

Metode pembangunan sistem yang diadopsi dalam penelitian ini adalah metode waterfall. Penelitian ini terdiri dari rangkaian proses berurutan dan sistematis dari tahapan analisis, desain, pengodean dan pengujian. Tahapan analisis dilakukan dengan menganalisis kebutuhan pengguna terhadap aplikasi. Berdasarkan kebutuhan fungsional dan non-fungsional telah dirumuskan, pada tahapan selanjutnya dirumuskan rancangan arsitektur sistem, rancangan basis data, rancangan user interface, dan rancangan proses dari aplikasi. Tahapan pengodean dilakukaan untuk menterjemahkan hasil rancangan yang ada menjadi kode aplikasi. Di tahap akhir, pengujian dilakukan oleh pengguna dengan cara menguji fungsional sistem secara langsung untuk memastikan aplikasi yang dibangun telah berjalan sesuai dengan fungsional yang ada

Data-data yang dibutuhkan berupa data spasial dan data atribut. Data atribut diperoleh dari BP4K2P Kabupaten Agam tahun 2015. Digitasi data spasial dilakukan dengan menggunakan MapInfo Professional. Digitasi diawali dengan melakukan obsevarsi ke masing-masing kelompok tani dan mendapatkan informasi spasial dari setiap lokasi kelompok tani. Titik koordinat berupa longitude dan latitude diambil dengan menggunakan perangkat GPS Garmin Montana.

\section{HASIL DAN PEMBAHASAN}

\subsection{Analisis Kebutuhan}

Tahapan analisis dilakukan dengan menganalisis kebutuhan pengguna terhadap aplikasi. Analisis kebutuhan fungsional dimodelkan dalam context diagram, dan data flow diagram level 1.

\subsubsection{Kebutuhan Fungsional}

Kebutuhan fungsional aplikasi ini dibangun berdasarkan data dan wawancara dengan UPT.BP4K2P. Kebutuhan fungsional untuk aplikasi yang dibangun adalah sebagai berikut:

1. Pengguna dapat melihat posisinya pada saat menggunakan sistem.
2. Pengguna dapat melakukan pencarian lokasi kelompok tani berdasarkan nama kelompok tani

3. Pengguna dapat melakukan pencarian lokasi kelompok tani berdasarkan kenagarian.

4. Pengguna dapat melakukan pencarian lokasi kelompok tani berdasarkan komoditi unggulan.

5. Pengguna dapat melihat informasi setiap kelompok tani

6. Pengguna dapat melihat rute menuju kelompok tani yang dipilih.

7. Pengguna dapat melakukan melakukan login ke sistem

8. Pengguna yang telah tervalidasi dapat mengelola informasi yang dikirimkan ke setiap kelompok tani

\subsubsection{Kebutuhan Data Spasial}

Kebutuhan data spasial pada pembangunan aplikasi ini dapat dilihat pada gambar 1 .

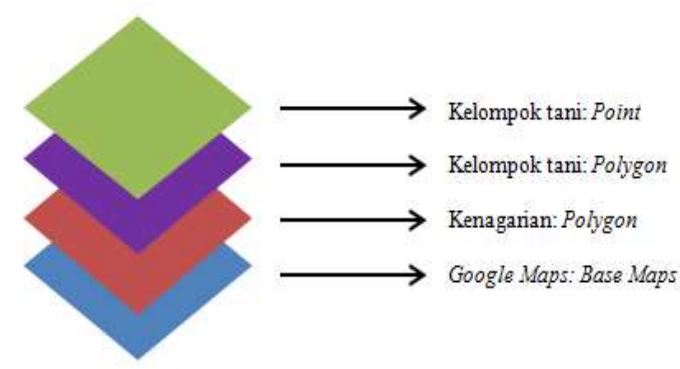

Gambar 1. Layer data spasial

\subsubsection{Context Diagram}

Pada context diagram ini pengguna memberikan masukan kepada sistem berupa data request dan pengguna akan menerima keluaran dari sistem berupa data kelompok tani. Sedangkan Google Maps akan memberikan masukan berupa layanan peta dasar kepada sistem. Data flow diagram level 0 pembangunan aplikasi SIG penyebaran kelompok tani Kabupaten Agam dapat dilihat pada Gambar 2

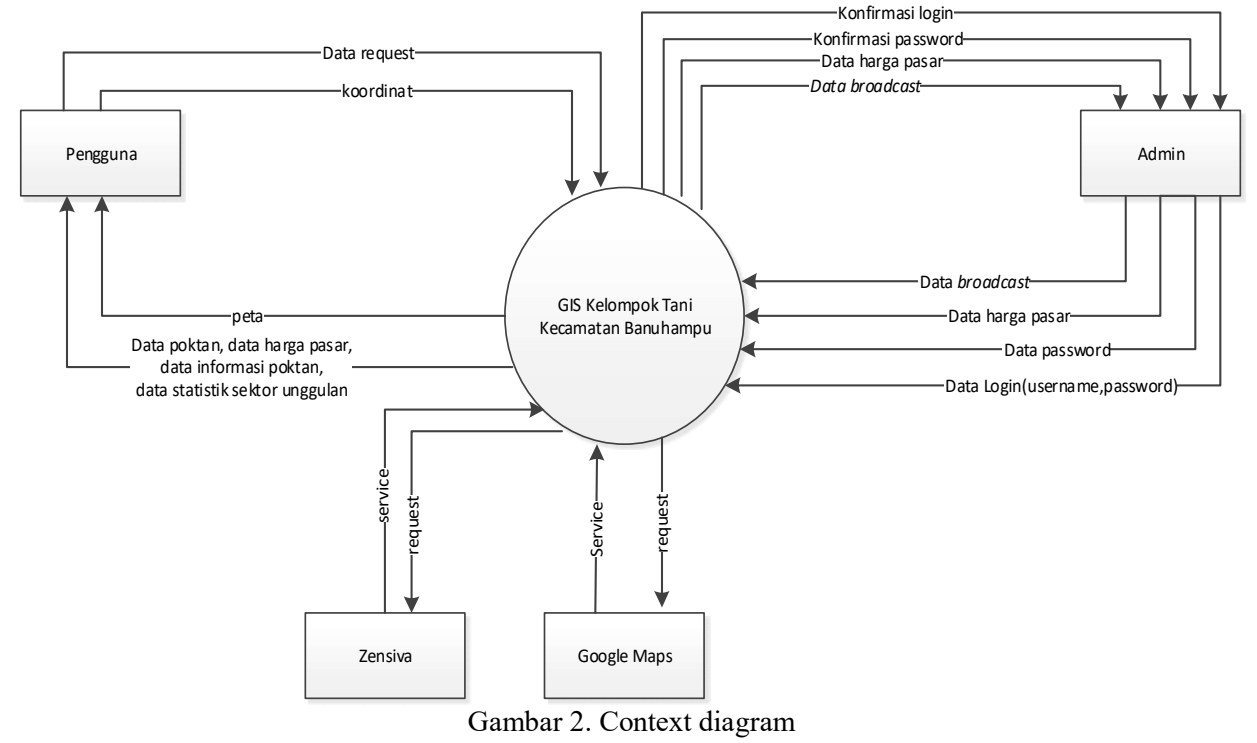




\subsection{Rancangan}

Rancangan sistem yang dihasikan adalah rancangan arsitektur sistem, rancangan basis data, rancangan antarmuka, dan rancangan proses.

\subsubsection{Rancangan Arsitektur Sistem}

Rancangan arsitektur terdiri dari sisi client dan sisi server. Rancangan arsitektur dapat dilihat pada Gambar .

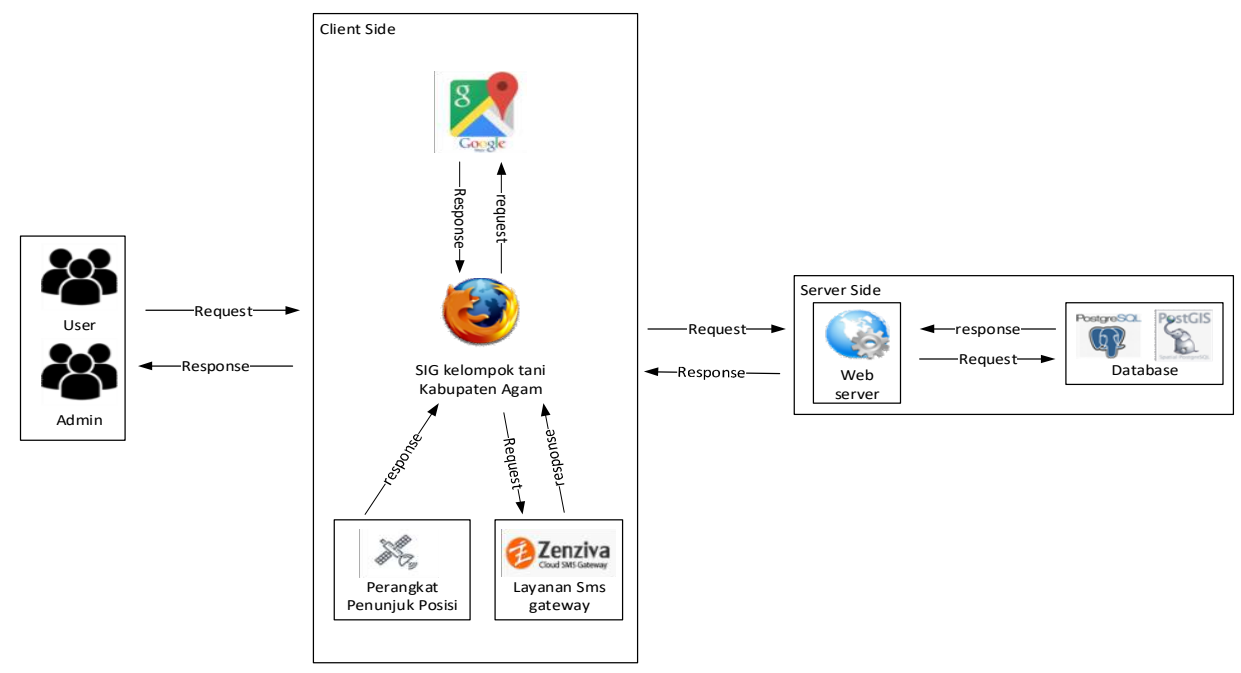

Gambar 3. Arsitektur aplikasi sistem

Database server yang digunakan dalam aplikasi ini adalah PostgreSQL yang menyimpan data atribut maupun data spasial. Data dengan tipe geometry diubah ke dalam format JSON dengan bantuan SQL dari fungsi yang ada pada PostGIS, sehingga data hasil digitasi dapat ditampilkan pada Google Maps. API Google Maps memberikan layanan kebutuhan peta dasar bagi aplikasi.

\subsubsection{Rancangan Basis Data}

Perancangan basis data untuk pembangunan SIG kelompok tani Kabupaten Agam berbasis web terdiri dari 9 tabel. Rancangan basis data dari aplikasi dapat dilihat pada Gambar .

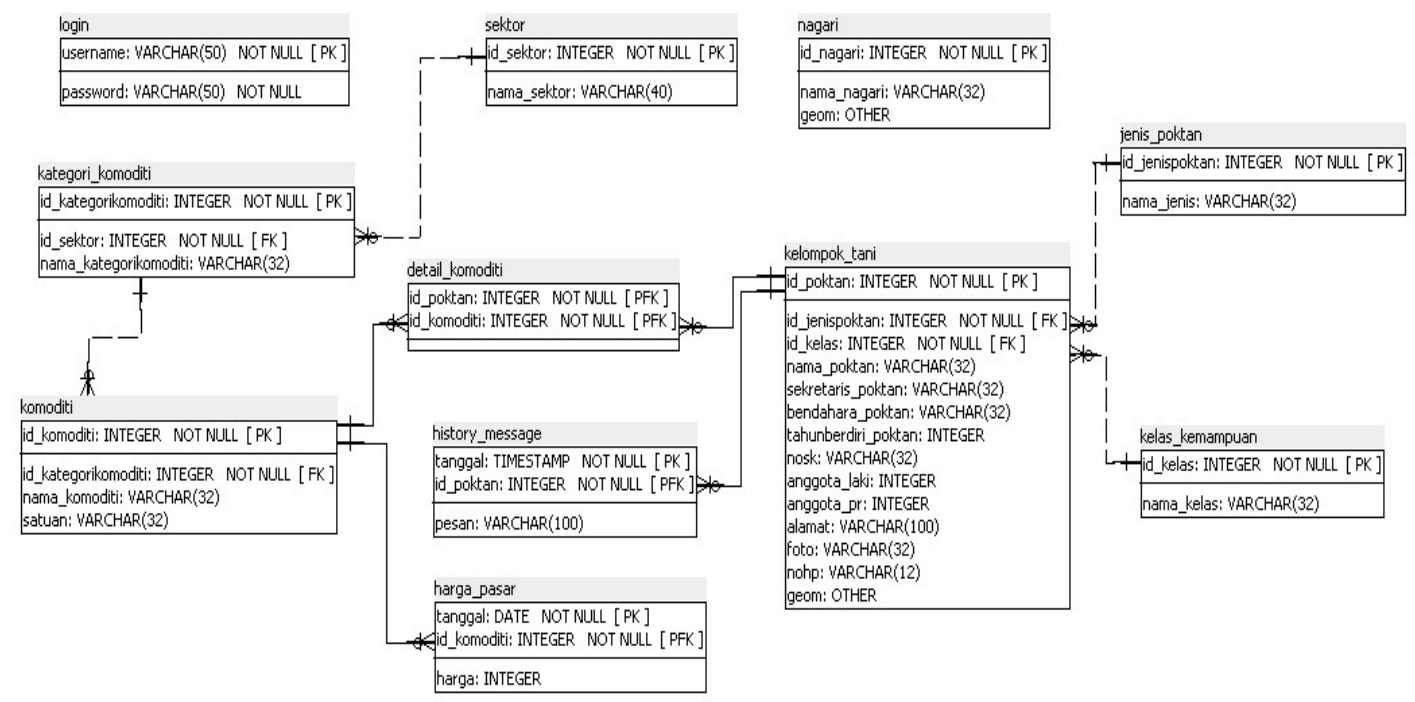

Gambar 4. Rancangan Basis Data Aplikasi SIG Kelompok Tani

\subsubsection{Rancangan User Interface}

Rancangan user interface untuk menampilkan informasi dari hasil pencarian kelompok tani akan tampil sebagai pop-up yang dapat dilihat pada Gambar. 5 


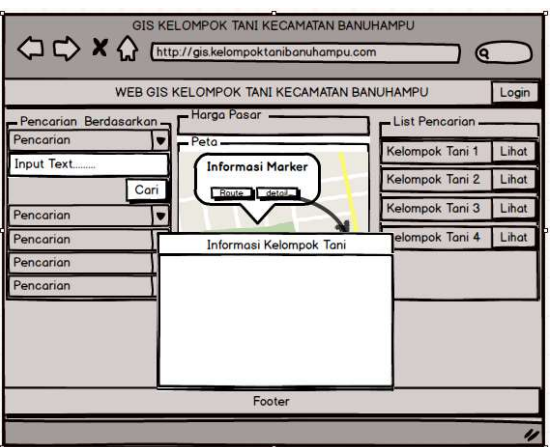

Gambar 5. Rancangan User Interface menampilkan Informasi

\subsubsection{Perancangan Proses}

Rancangan proses menggambarkan skenario aktivitas dan interaksi yang dilakukan oleh pengguna dengan sistem,

Tabel 1. Skenario mencari lokasi kelompok tani berdasarkan komoditas unggulan

\begin{tabular}{|c|c|}
\hline $\begin{array}{l}\text { Use case } \\
\text { name }\end{array}$ & $\begin{array}{l}\text { Mencari lokasi } \\
\text { berdasarkan komoditi }\end{array}$ \\
\hline Actor & Pengguna \\
\hline $\begin{array}{l}\text { Pre } \\
\text { condition }\end{array}$ & Pengguna telah membuka aplikasi \\
\hline $\begin{array}{l}\text { Normal } \\
\text { course }\end{array}$ & $\begin{array}{l}\text { 1. Pengguna memilih menu pencarian } \\
\text { "Berdasarkan Komoditi Unggulan" }\end{array}$ \\
\hline & $\begin{array}{l}\text { 2. Sistem menampilkan form } \\
\text { pencarian berupa combo box }\end{array}$ \\
\hline & $\begin{array}{l}\text { 3. Pengguna memilih sektor unggulan } \\
\text { 4. Sistem menampilkan form } \\
\text { pencarian berupa combo box }\end{array}$ \\
\hline
\end{tabular}

5. Pengguna memilih kategori komoditi unggulan
6. Sistem menampilkan form pencarian berupa combo box

7. Pengguna memilih komoditi unggulan dan menekan tombol "Cari"

8. Sistem melakukan pengecekan data yang dicari pada database

9. Sistem menampilkan hasil pencarian

\begin{tabular}{ll}
\hline $\begin{array}{l}\text { Exit } \\
\text { condition }\end{array}$ & $\begin{array}{l}\text { Muncul marker peta dan nama kelompok tani } \\
\text { pada hasil pencarian berdasarkan komoditi } \\
\text { unggulan yang dipilih }\end{array}$ \\
\hline $\begin{array}{l}\text { Alternative } \\
\text { Course }\end{array}$ & 1. $\begin{array}{c}\text { Pengguna memilih menu pencarian } \\
\text { "Berdasarkan Komoditi Unggulan" }\end{array}$ \\
& 2. $\quad \begin{array}{l}\text { Sistem menampilkan form } \\
\text { pencarian berupa combo box }\end{array}$
\end{tabular}

3. Pengguna memilih sektor unggulan

4. Sistem menampilkan form pencarian berupa combo box

5. Pengguna memilih kategori komoditi unggulan

6. Sistem menampilkan form pencarian berupa combo box

7. Pengguna memilih komoditi unggulan dan menekan tombol "Cari"

8. Sistem melakukan pengecekan data yang dicari pada database

9. Sistem menampilkan pesan "Data Tidak Ada"

Rancangan skenario mencari lokasi Kelompok Tani Berdasarkan Jenis dapat dilihat pada Tabel 1. Skenario ini menggambarkan

337 Yossi Prima Ariyani urutan aktivitas yang digunakan untuk mencari lokasi kelompok tani berdasarkan jenis kelompok tani.

\subsection{Implementasi Sistem}

User interface untuk aplikasi web ini hanya terdiri dari beberapa halaman. Halaman utama yang memuat menu-menu yang disediakan oleh aplikasi yang dapat dilihat pada Gambar 6 .

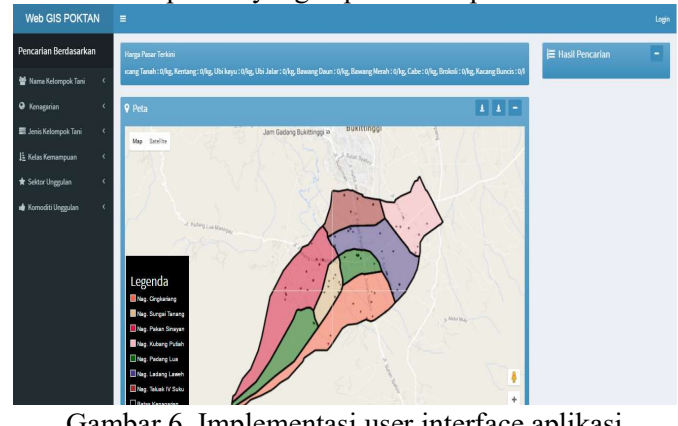

Gambar 6. Implementasi user interface aplikasi

Halaman yang menampilkan rute menuju kelompok tani yang dipilih dapat dilihat pada Gambar 7.

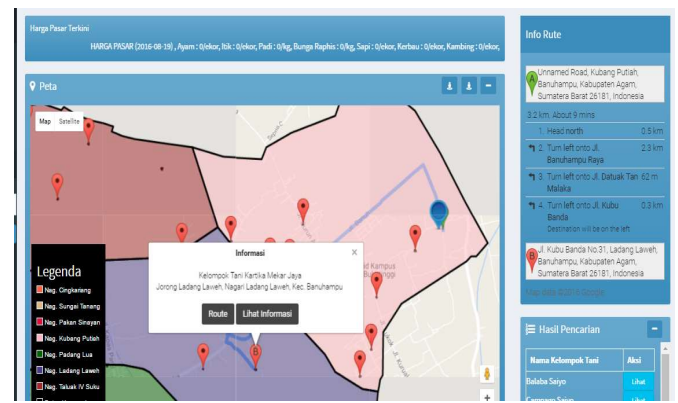

Gambar 7. Implementasi user interface menampilkan info rute

\subsection{Pengujian Sistem}

Pengujian sistem dilakukan menggunakan metode blackbox testing dengan mengamati masukan yang diberikan kepada sistem dan keluaran yang dihasilkan oleh sistem.

\subsubsection{Pengujian Fungsional Mencari Lokasi Kelompok Tani Berdasarkan Nama}

Pengujian yang dilakukan adalah mencari lokasi kelompok tani berdasarkan nama. Hasil akhir dari pengujian ini adalah aplikasi menampilkan lokasi kelompok tani berdasarkan nama yang diinput-kan oleh pengguna dan aplikasi menampilkan marker lokasi kelompok tani tersebut pada peta. Pada pengujian ini pengguna memasukkan nama kelompok tani "amanah agro". Hasil pengujian fungsional mencari lokasi kelompok tani berdasarkan nama kelompok tani dapat dilihat pada Tabel. Hasil pengujian pada aplikasi web dapat dilihat pada Gambar 8.

Tabel 2. Hasil pengujian mencari lokasi kelompok tani berdasarkan nama

\begin{tabular}{ll}
\hline Nomor tes & $\mathbf{0 2}$ \\
\hline Aksi & $\begin{array}{l}\text { Pengguna memasukkan kata kunci nama } \\
\text { kelompok tani "amanah agro" dan menekan } \\
\text { tombol "Cari" }\end{array}$ \\
\hline Ekspektasi & $\begin{array}{l}\text { Muncul marker pada peta dan nama kelompok } \\
\text { tani Amanah Agro pada hasil pencarian }\end{array}$ \\
\hline $\begin{array}{l}\text { Hasil } \\
\text { Pengujian }\end{array}$ & Sesuai dengan ekspektasi \\
\hline Kesalahan & Tidak ada \\
\hline
\end{tabular}

https://doi.org/10.25077/ TEKNOSI.v3i3.2017.334-342 


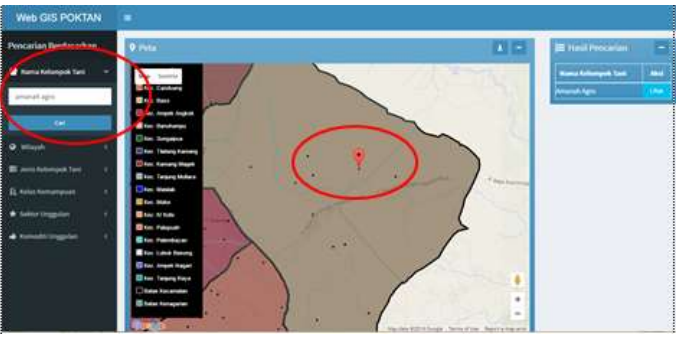

Gambar 8. Pengujian mencari lokasi kelompok tani berdasarkan nama

Pengujian juga dilakukan pada query SQL untuk melihat kesesuaian data yang ditampilkan apliaksi dengan data yang ada pada basis data. Hasil pengujian yang didapatkan dengan menggunakan SQL pada basis data dapat dilihat pada Gambar 9.

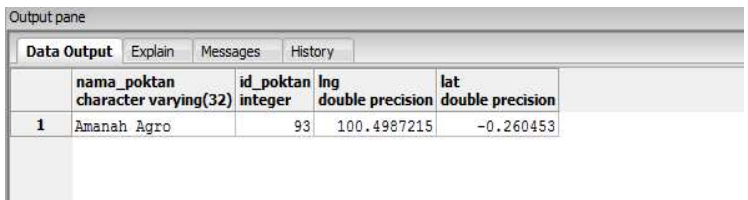

Gambar 9. Hasil pengujian query SQL mencari lokasi kelompok tani berdasarkan nama kelompok tani

Dari hasil pengujian ini disimpulkan bahwa fungsional mencari lokasi kelompok tani berdasarkan nama pada aplikasi SIG kelompok tani Kabupaten Agam berbasis web telah sesuai dengan yang diharapkan dan hasilnya sesuai dengan data yang ada dalam basis data.

\subsubsection{Pengujian Mencari Lokasi Kelompok Tani Berdasarkan Kenagarian}

Pengujian yang dilakukan adalah mencari lokasi kelompok tani berdasarkan kenagarian. Hasil akhir dari pengujian ini adalah aplikasi menampilkan lokasi kelompok tani berdasarkan kenagarian yang dipilih oleh pengguna dan aplikasi menampilkan marker lokasi kelompok tani tersebut pada peta.

Pengujian dilakukan misalnya dengan memilih Kecamatan Kamang Magek dan Kenagarian Kamang Mudiak. Prosedur pengujian fungsional mencari lokasi kelompok tani berdasarkan kenagarian dan hasil pengujian dapat dilihat pada Tabel 3 dan Gambar 10 .

Tabel 3. Hasil pengujian mencari lokasi kelompok tani berdasarkan kenagarian

\begin{tabular}{ll}
\hline Nomor tes & $\mathbf{0 4}$ \\
\hline Aksi & $\begin{array}{l}\text { Pengguna memilih Kecamatan Kamang } \\
\text { Magek pada pencarian berdasarkan wilayah } \\
\text { selanjutnya memilih Kenagarian Kamang } \\
\text { Mudiak pada menu kenagarian dan } \\
\text { menekan tombol "Cari" }\end{array}$ \\
\hline Ekspektasi & $\begin{array}{l}\text { Muncul marker pada peta dan nama } \\
\text { kelompok tani yang berada di Kenagarian }\end{array}$ \\
& $\begin{array}{l}\text { Kamang Mudiak pada hasil pencarian } \\
\text { berdasarkan }\end{array}$ \\
\hline Hasil & Sesuai dengan ekspektasi \\
\hline Kesalahan & Tidak ada \\
\hline
\end{tabular}

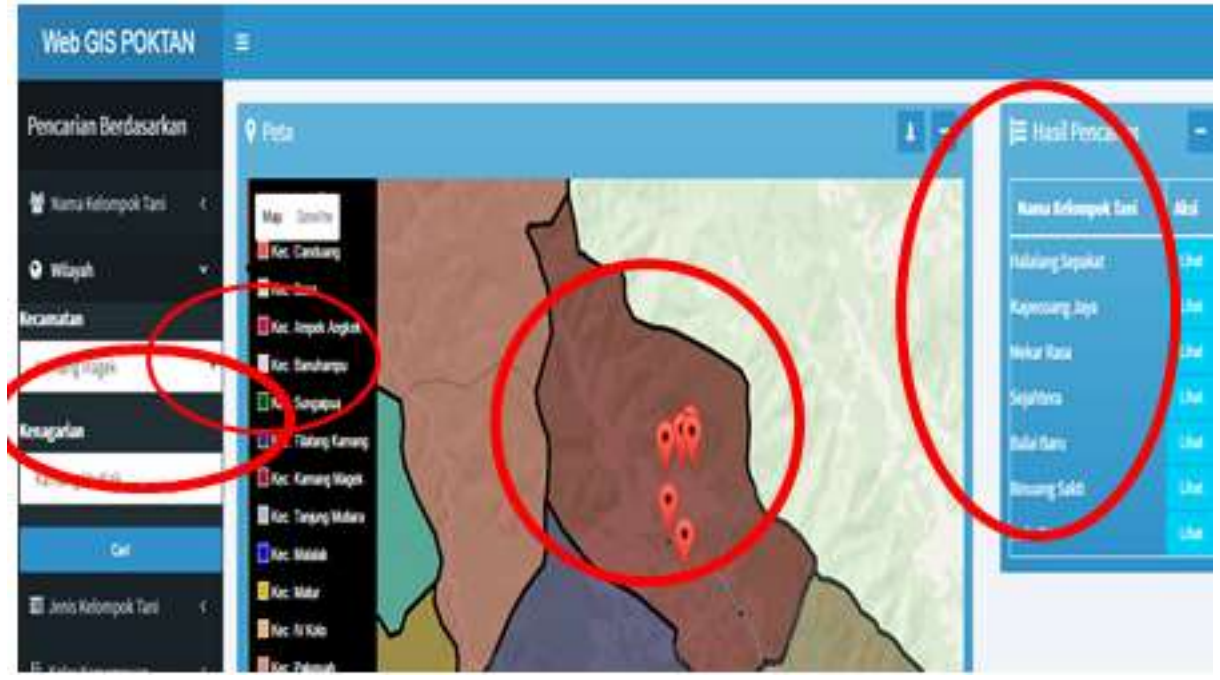

Gambar 10. Pengujian mencari lokasi kelompok tani berdasarkan kenagarian

Pengujian juga dilakukan pada query SQL untuk melihat keseuaian data yang ditampilkan aplikasi dengan data yang ada pada basis data. Pengujian pada query $S Q L$ tersebut dilakukan untuk mendapatkan data kelompok tani berdasarkan kenagarian yang telah dipilih yaitu Kenagarian Kamang Mudiak dengan id_nagari adalah 20. Hasil pengujian yang didapatkan dengan menggunakan SQL pada basis data dapat dilihat pada Gambar.11

Hasil pengujian memperlihatkan bahwa fungsional mencari lokasi kelompok tani berdasarkan kenagarian pada peta pada aplikasi telah sesuai dengan yang dirancang.

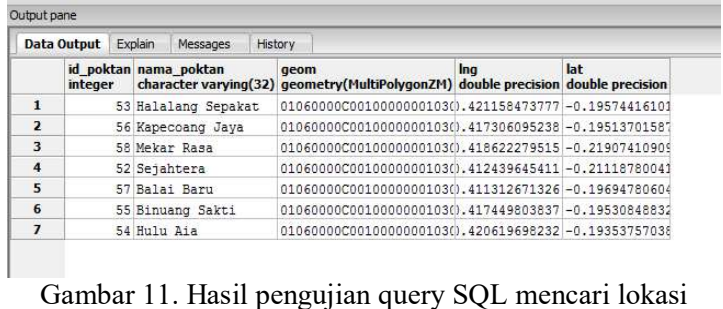

kelompok tani berdasarkan Kenagarian Kamang Mudiak 


\subsubsection{Pengujian Mencari Lokasi Kelompok Tani Berdasarkan Komoditi Unggulan}

Pengujian yang dilakukan adalah mencari lokasi kelompok tani berdasarkan komoditi unggulan. Prosedur pengujian fungsional mencari lokasi berdasarkan komoditi unggulan dapat dilihat pada Tabel . Hasil pengujian pada aplikasi web dapat dilihat pada Gambar 11.

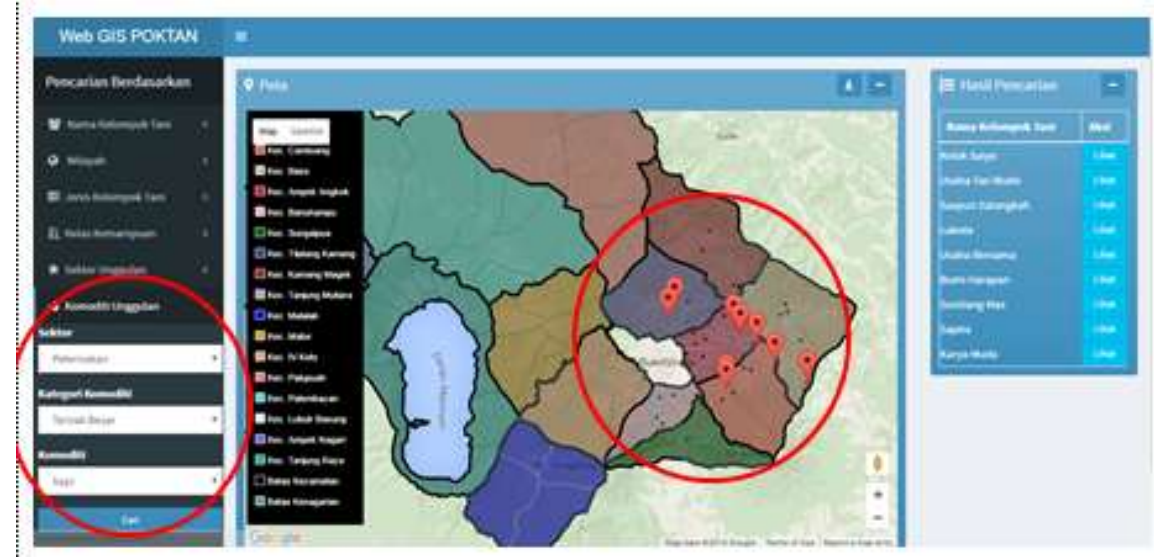

Gambar 11. Pengujian mencari lokasi kelompok tani berdasarkan komoditi unggulan

Tabel 4. Hasil pengujian mencari lokasi kelompok tani berdasarkan komoditi unggulan

\begin{tabular}{ll}
\hline Nomor tes & $\mathbf{0 8}$ \\
\hline Aksi & $\begin{array}{l}\text { Pengguna memilih sektor peternakan pada } \\
\text { combo box sektor selanjutnya memilih } \\
\text { kategori komoditi ternak besar pada combo } \\
\text { box kategori komoditi dan memilih komoditi } \\
\text { sapi pada combo box komoditi lalu menekan } \\
\text { tombol "Cari" }\end{array}$ \\
\hline Ekspektasi & $\begin{array}{l}\text { Muncul marker pada peta dan nama } \\
\text { kelompok tani yang memiliki komoditi } \\
\text { unggulan sapi pada hasil pencarian }\end{array}$ \\
\hline Hasil & Sesuai dengan ekspektasi \\
\hline Kesalahan & Tidak ada \\
\hline
\end{tabular}

Hasil pengujian dibandingkan dengan hasil SQL pada basis data yang dapat terlihat di Gambar. Hasil pengujian menunjukkan bahwa luaran aplikasi telah sesuai sesuai dengan data yang ada.

\subsubsection{Pengujian Melihat Rute Menuju Lokasi Kelompok Tani}

Hasil dari pengujian ini adalah aplikasi menampilkan rute menuju lokasi kelompok tani yang dipilih oleh pengguna. Pengujian yang dilakukan oleh pengguna dengan memilih kelompok tani Mawar Budi dan melihat rute menuju kelompok tani tersebut. Pengguna berada pada titik koordinat $-0.303892,100.383455$. Prosedur

Berdasarkan pengujian yang dilakukan oleh penulis dan pengguna menunjukkan bahwa aplikasi yang dibangun telah sesuai dengan fungsional yang dirancang. Hasil pengujian tersebut didapatkan dari hasil pengujian yang telah dilakukan oleh pembuat aplikasi dan pengguna yang terdiri dari lima orang.

339 Yossi Prima Ariyani pengujian dapat dilihat pada Tabel 5 . Hasil pengujian dapat dilihat pada

Gambar.14.

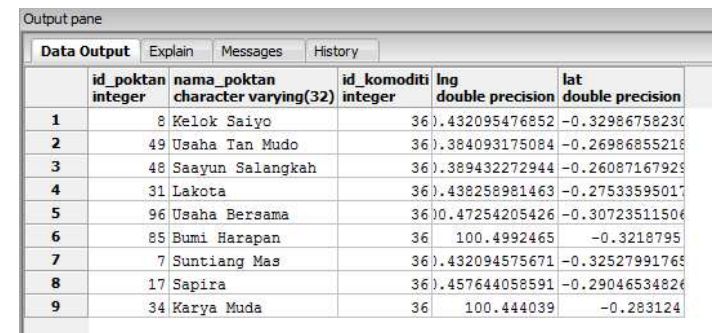

Gambar 13. Hasil pengujian query SQL posisi kelompok tani berdasarkan komoditi sapi

Tabel 5. Hasil pengujian melihat rute menuju lokasi kelompok tani

\begin{tabular}{|c|c|}
\hline Nomor tes & 12 \\
\hline Aksi & $\begin{array}{l}\text { Pengguna berada pada titik koordinat - } \\
0.303892,100.383455 \text { dan mengklik icon } \\
\text { posisi saat ini, selanjutnya memilih tombol } \\
\text { "Route" pada info window kelompok tani } \\
\text { Mawar Budi }\end{array}$ \\
\hline Ekspektasi & $\begin{array}{l}\text { Muncul rute menuju lokasi kelompok tani } \\
\text { mawar budi dari posisi pengguna yang } \\
\text { berada pada titik koordinat }-0.303892 \text {, } \\
100.383455\end{array}$ \\
\hline Hasil & Sesuai dengan ekspektasi \\
\hline Kesalahan & Tidak ada \\
\hline
\end{tabular}

Dengan demikian dapat diperoleh bahwa aplikasi sudah berjalan dan sesuai dengan fungsional sistem yang direncanakan.

\subsubsection{Pengujian Mengelola Data Harga Pasar}

Pengujian mengelola data harga pasar ini terdiri dari empat aktivitas yaitu menambah data harga pasar, mengubah dat harga pasar, melihat data harga pasar, dan melihat riwayat data

https://doi.org/10.25077/ TEKNOSI.v3i3.2017.334-342 
harga pasar. Pengelolaan data harga pasar ini hanya bisa dilakukan jika elah melakukan login ada aplikasi.

a. Pengujian Menambah Data Harga Pasar

Pengujian yang dilakukan berikut ini merupakan pengujian proses menambahkan harga pasar. Prosedur pengujian menambahkan harga pasar dapat dilihat pada Tabel .6
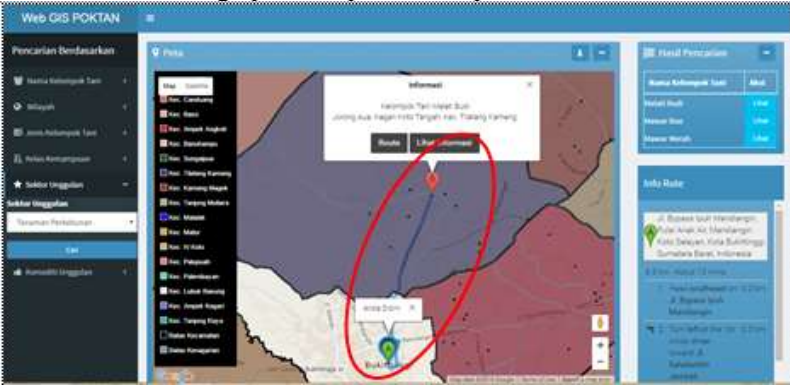

Gambar 14. Pengujian melihat rute menuju kelompok tani Mawar Budi

Tabel 6. Prosedur Menambah Data Harga Pasar

\begin{tabular}{ll}
\hline Nomor tes & $\mathbf{1 1}$ \\
\hline Kasus dan Hasil Uji (Data Normal) \\
\hline Aksi & $\begin{array}{l}\text { Pengguna menginputkan harga pada tanggal 16 } \\
\text { Agustus 2016 lalu mengklik button "Insert } \\
\text { Harga" dan memasukkan harga pasar }\end{array}$ \\
\hline Ekspektasi & $\begin{array}{l}\text { Muncul pesan bahwa data telah } \\
\text { ditambahkan dan sistem menyimpan data } \\
\text { lalu kembali ke halaman harga dengan } \\
\text { menampilkan harga yang terakhir } \\
\text { diinputkan }\end{array}$ \\
\hline Hasil & Sesuai dengan ekspektasi \\
\hline Kesalahan & Tidak ada \\
\hline Kasus dan Hasil Uji (Data Tidak Normal) \\
\hline Aksi & $\begin{array}{l}\text { ydmin menginputkan harga pada tanggal } \\
\text { yang sama yaitu pada tanggal 16 Agustus }\end{array}$ \\
\hline 2016 \\
\hline Kasil & $\begin{array}{l}\text { Muncul pesan bahwa data sudah pernah } \\
\text { dimasukkan }\end{array}$ \\
\hline & Sesuai dengan ekspektasi \\
\hline
\end{tabular}

Untuk melakukan proses ini pengguna telah berhasil login pada aplikasi. Pada pengujian ini terdapat dua kondisi bagi pengguna agar dapat menginputkan harga pasar. Kondisi pertama pengujian dengan kondisi data normal. Pada tanggal 16 Agustus 2016, pengguna telah memasukkan harga dimana pada tanggal tersebut belum pernah dilakukan pemasukan harga sehingga fungsional menambahkan harga dapat dilakukan. Jika data berhasil ditambahkan makan akan muncul pesan bahwa data telah berhasil ditambah yang dapat dilihat pada Gambar

Kondisi kedua merupakan pengujian data tidak normal, admin akan menginput harga pada tanggal 16 Agustus 2016 dimana sebelumnya admin telah melakukan input harga pada tanggal tersebut. Hasil dari sistem dapat dilihat pada gambar 16.

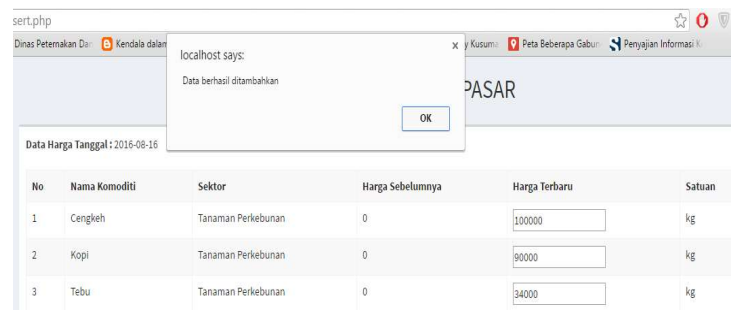

Gambar 15. Sistem Menampilkan Pesan Data Telah Berhasil Ditambahkan

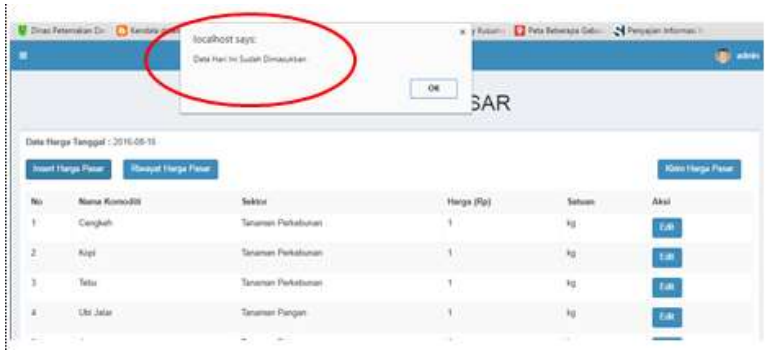

Gambar 16. Hasil Pengujian Data Tidak Normal Menambah Harga Pasar

\section{b. Pengujian Melihat Data Harga Pasar}

Pengujian yang dilakukan berikut ini merupakan pengujian fungsional melihat harga pasar komoditi yang terdapat pada halaman admin. Prosedur pengujian melihat data harga pasar dapat dilihat pada Tabel. 7

Tabel 7. Prosedur Melihat Data Harga Pasar

\begin{tabular}{ll}
\hline Nomor tes & $\mathbf{1 1}$ \\
\hline Kasus dan Hasil Uji \\
\hline Aksi & Admin mengklik halaman "harga pasar" \\
\hline Ekspektasi & $\begin{array}{l}\text { Sistem menampilkan harga pasar yang } \\
\text { terakhir kali diinputkan }\end{array}$ \\
\hline Hasil & Sesuai dengan ekspektasi \\
\hline Kesalahan & Tidak ada \\
\hline
\end{tabular}

Untuk melakukan proses ini admin telah berhasil login pada aplikasi. Dalam pengujian ini data harga pasar telah diinputkan pada tanggal 15 dan 16 Agustus 2016 sehingga sistem menampilkan data harga yang terakhir kali di inputkan. Hasil pengujian melihat harga pasar dapat dilihat pada gambar 17 .

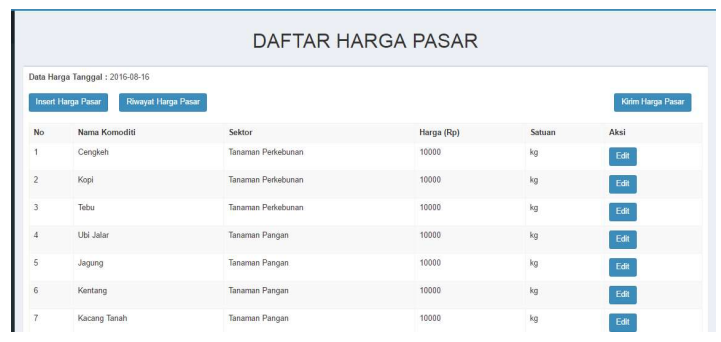

Gambar 17. Hasil Pengujian Melihat History Harga Pasar

Selanjutnya dilakukan pengujian query SQL dapat dilihat pada seperti gambar 18 dan hasil pengujian Query dapat dilihat pada gambar 19.

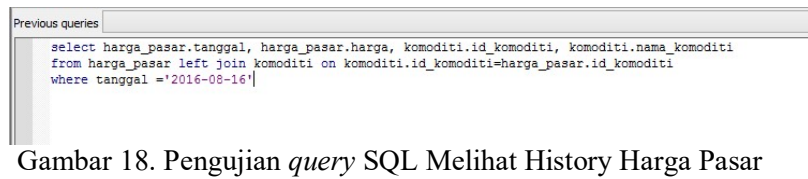

Gambar 18. Pengujian query SQL Melihat History Harga Pasar 


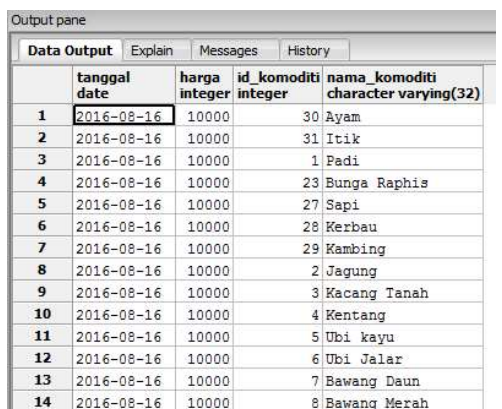

Gambar 19. Hasil Pengujian Query SQL Melihat Harga Pasar

Dari hasil pengujian ini disimpulkan bahwa fungsional melihat harga pasar pada aplikasi SIG kelompok tani Kecamatan Banuhampu berbasis web telah sesuai dengan yang diharapkan dan telah sesuai data yang terdapat pada basis data.

c. Pengujian Melihat Data Riwayat Harga Pasar Pengujian yang dilakukan berikut ini merupakan pengujian fungsional melihat history harga pasar. Prosedur pengujian melihat riwayat harga pasar dapat dilihat pada Tabel 8.

Tabel 8. Prosedur Melihat Riwayat Harga Pasar

\begin{tabular}{ll}
\hline Nomor tes & $\mathbf{1 1}$ \\
\hline Kasus dan Hasil Uji & $\begin{array}{l}\text { Admin memilih halaman "Riwayat Harga" pada } \\
\text { tanggal 16 Agustus 2016 }\end{array}$ \\
\hline Aksi & $\begin{array}{l}\text { Sistem menampilkan riwayat harga pasar } \\
\text { yang pernah diinputkan. }\end{array}$ \\
\hline Ekspektasi & Sesuai dengan ekspektasi \\
\hline Kesalahan & Tidak ada \\
\hline
\end{tabular}

Pengguna dapat melakukan fungsional tersebut jika sebelumnya telah menginputkan harga pasar. Dalam pengujian ini admin memilih harga pasar pada tanggal 16 Agustus 2016 sehingga sistem menampilkan data harga pasar pada tanggal 16 Agustus 2016. Hasil pengujian melihat riwayat harga pasar dapat dilihat pada gambar 20.

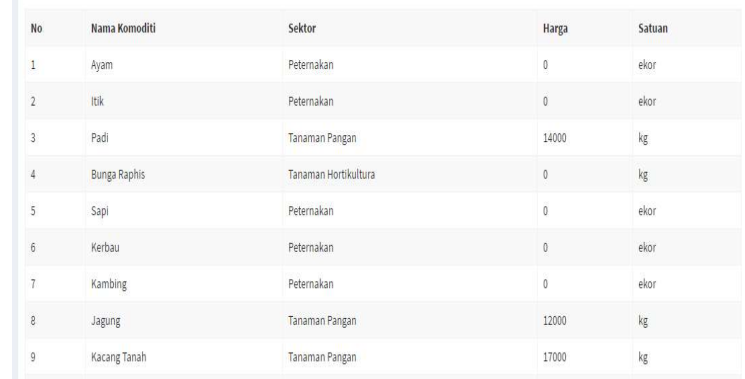

Gambar 20. Hasil Pengujian Melihat History Harga Pasar

\subsubsection{Pengujian Mengirim Informasi Harga Pasar Kepada Kelompok Tani}

Pengujian yang dilakukan berikut ini merupakan pengujian fungsional mengirim informasi harga pasar kepada kelompok tani. Prosedur pengujian mengirim informasi harga pasar kepada kelompok tani dapat dilihat pada tabel 9.

Tabe1 9. Prosedur Mengirim Informasi Harga kepada Kelompok Tani

341 Yossi Prima Ariyani

\begin{tabular}{ll}
\hline Nomor tes & $\mathbf{1 1}$ \\
\hline Kasus dan Hasil Uji (Data Normal) \\
\hline Aksi & $\begin{array}{l}\text { Admin memilih button "kirim harga" pada } \\
\text { tanggal 21 agustus 2016 lalu sistem } \\
\text { menampilkan berupa pop-up yang berisikan } \\
\text { pesan yang akan dikirimkekelompok tani }\end{array}$ \\
\hline Ekspektasi & $\begin{array}{l}\text { Sistem mengirim broadcast ke kelompok } \\
\text { tani dan menyimpan dalam halaman } \\
\text { "Riwayat Broadcast" }\end{array}$ \\
\hline Hasil & Sesuai dengan ekspektasi \\
\hline Kesalahan & Tidak ada \\
\hline Kasus dan Hasil Uji (Data Tidak Normal) \\
\hline Aksi & $\begin{array}{l}\text { Admin belum menginputkan harga pasar dan } \\
\text { memilih button "kirimharga" }\end{array}$ \\
\hline Ekspektasi & $\begin{array}{l}\text { Sistem menampilkan berupa pop-up } \\
\text { kosong }\end{array}$ \\
\hline Hasil & Sesuai dengan ekspektasi \\
\hline Kesalahan & Tidak ada \\
\hline
\end{tabular}

Pada pengujian ini terdapat dua kondisi pengguna dalam mengirimkan harga pasar kepada kelompok tani, yang pertama adalah pada pengujian data normal. Dalam pengujian ini pengguna melakukan melakukan fungsional tersebut pada tanggal 21 Agustus 2018, dan data yang terakhir diinputkan adalah data pada tanggal 20 Agustus 2016, lalu pengguna mengklik tombol "kirim harga". Maka akan muncul pop up berupa pesan yang akan dikirim kepada kelompok tani pada tanggal 21 Agustus 2016 dengan harga pasar pada tanggal 20 Agustus 2016 yang dapat dilihat pada gambar 21. Hasil pengujian data normal mengirim informasi harga pasar kepada kelompok tani dapat dilihat pada gambar 22 .

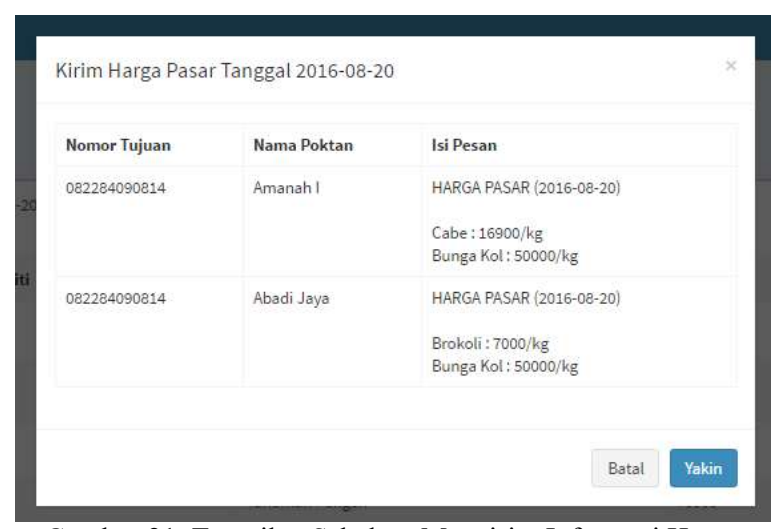

Gambar 21. Tampilan Sebelum Mengirim Informasi Harga Pasar Kepada Kelompok Tani

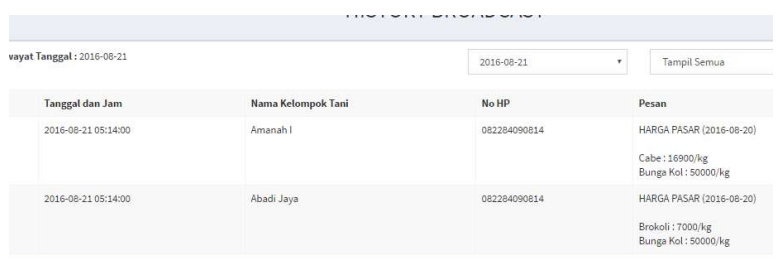

Gambar 22. Hasil Pengujian Data Normal Mengirim Informasi Harga Pasar Kepada Kelompok Tani

Dari hasil pengujian ini disimpulkan bahwa fungsional mengirin informasi harga pasar kepada kelompok tani pada aplikasi SIG kelompok tani Kecamatan Banuhampu berbasis web telah sesuai dengan yang diharapkan.

https://doi.org/10.25077/ TEKNOSI.v3i3.2017.334-342 


\section{KESIMPULAN}

Aplikasi SIG penyuluh tani Kabupaten Agam telah dibangun. Berdasarkan rangkain kegiatan penelitian yang dilakukan dapat disimpulkan beberapa hal-hal berikut:

1. Analisis kebutuhan fungsioanl dilakukan dengan menganalisis data BP4K2P 2015 dan kebutuhan pengguna. Hasil yang didapatkan adalah 7 kebutuhan fungsional sistem yang terdiri dari pencarian berdasarkan nama, kenagarian, jenis kelompok, komoditi unggulan, melihat informasi kelompok, dan rute menuju kelompok tani.

2. SIG kelompok tani Kabupaten Agam berbasis web telah dibangun. Analisis kebutuhan fungsional terdiri dari 7 kebutuhan fungsional sistem serta 5 layer data spasial.

3. Pengujian dengan blackbox testing pada kebutuhan fungsional dari sistem didapatkan bahwa 7 kebutuhan fungsional tersebut telah berjalan sesuai dengan hasil rancangan.

\section{DAFTAR PUSTAKA}

[1] Nuryanti, Sri, and Dewa Ketut Sadra Swastika. "Peran kelompok tani dalam penerapan teknologi pertanian." In Forum Penelitian Agro Ekonomi, vol. 29, no. 2, pp. 115-128. 2016.

[2] Wijaya, Andri, and Olvhie Ayundha. "Sistem Informasi Geografis Pemetaan Kantor Dinas Pemerintah Kota Palembang menggunakan ArcGIS." Semantik 2014 (2014).

[3] Manan, Abdul, Husain Husain, and Ni Ketut Sri Winarti. "Geographic Information System: Sistem Informasi Pembuatan Model Pengendalian Kepemelikan Ternak Sapi di Wilayah Provinsi NTB." In Seminar Nasional Informatika (SEMNASIF), vol. 1, no. 1. 2015.

[4] Harison, Harison, and Fuji Kurniawan. "Aplikasi Sistem Informasi Geografis Produksi Padi dan Cabe di Kabupaten Lima Puluh Berbasis Android." Jurnal Teknologi dan Sistem Informasi 3, no. 1 (2017): 43-50.

[5] Pratikno, Harri Singgih. "Sistem Pencarian dan Pemesanan Rumah Kost Menggunakan Sistem Informasi Geografis (SIG)." Institut Sains dan Teknologi AKPRIND Yogyakarta (2014).

[6] Layona, Rita, and Budi Yulianto. "Aplikasi Pencarian Informasi dan Lokasi Tempat Makan pada Perancangan Mobile Berbasis Android" Jurnal Teknologi dan Sistem Informasi 2.2 (2016): 9-16.

[7] Gusmão, António, Sholeh Hadi Pramono, and Sunaryo Sunaryo. "Sistem Informasi Geografis Pariwisata Berbasis Web Dan Pencarian Jalur Terpendek Dengan P Algoritma Dijkstra." Jurnal EECCIS 7, no. 2 (2013): 125-130.

[8] Yuhana, Umi Laili, O. Cahyadi, and H. Fabroyir. "Pemanfaatan Google Maps Untuk Pemetaan dan Pencarian Data Perguruan Tinggi Negeri di Indonesia." Alumni Jurusan Teknik Informatika, Fakultas Teknologi Informasi, Institut Teknologi Sepuluh Nopember. Sisfo-Jurnal Sistem Informasi (2010).

[9] Fajaruddin, Nur, and Ali Tarmuji. "Pembangunan Sistem Pencarian Lokasi Dengan Geolocation Berdasarkan GPS Berbasis Mobile Web (Studi Kasus Pencarian Lokasi Hotel di Yogyakarta)." Jurnal Sarjana Teknik Informatika 1, no. 1 (2013).

[10] R. R. Siahaan, K. I. Satoto, and K. T. Martono, "Implementasi Sistem Informasi Geografis Daerah Pariwisata Kota Semarang Berbasis Android dengan Global Positioning System (GPS)," Jurnal Teknologi dan Sistem Komputer, vol. 2, no. 1, pp. 96-109, Jan.
2014. doi: 10.14710/jtsiskom.2.1.2014.96-109, [Online].

\section{BIODATA PENULIS}

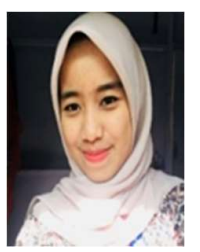

Yossi Prima Ariyani

Telah menerima gelar Sarjana Komputer dari Jurusan Sistem Informasi, Universitas Andalas pada tahun 2015. Saat ini telah bekerja di salah satu perusahaan IT dibidang IT developer di PT. Wahana Solusi Handal, Jakarta

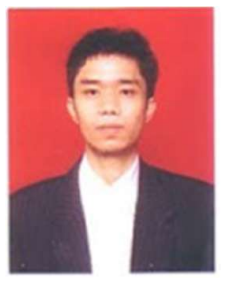

Haris Suryamen

Staff pengajar pada jurusan Sistem Informasi dan telah menyelesaikan magister bidang geoinformasi di University Technology Malaysia pada tahun 2009. Fokus bidang penelitian saat ini adalah sistem informasi geografis

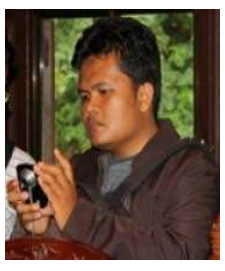

Fajril Akbar

Setelah menyelesaikan pendidikan magister di International Islamic University Malaysia tahun 2014, kembali aktif di jurusan sistem informasi, Universitas Andalas. Mata kuliah yang diampu saat ini arsitektur komputer dan dasar infrastruktur teknologi. 